\title{
THE EFFECT OF DESTRUCTION OF UTERO-OVARIAN VASCULAR CONNECTIONS ON THE LIFE-SPAN OF THE CORPUS LUTEUM IN SHEEP
}

\author{
W. DOBROWOLSKI* AND E. S. E. HAFEZ \\ Department of Gynecology-Obstetrics and Department of Physiology, \\ Wayne State University School of Medicine, Detroit, Michigan, U.S.A.
}

(Received 7th April 1970)

Several techniques, e.g. hysterectomy, embryo transfer, insertion of an IUD into the uterus, or experimentally induced inflammation of the uterus, have shown that the uterus influences the life-span of the corpus luteum (CL) (Anderson, Bowerman \& Melampy, 1963). Experiments with uterine transplantation indicate that afferent stimuli, which could cause release of gonadotrophins from the hypophysis, do not play an important rôle in this process (Melampy, Anderson \& Kragt, 1964). If, in sheep, the uterus is transplanted and the ovary left in the abdomen, the CL will persist, a result indicating the close relationship between the uterus and the ovary (Goding, McCracken \& Baird, 1967; McCracken \& Baird, 1969). When the endometrium in rats (Bradbury, Brown \& Gray, 1950), hamsters (Caldwell, Mazer \& Wright, 1967) and guinea-pigs (Butcher, Chu \& Melampy, 1962) was transplanted or destroyed chemically (Butcher et al., 1962) the results indicated that a luteolytic humoral substance originated from this part of the uterus. In sheep, homogenates of freeze-dried uteri injected into hysterectomized ewes do not reduce the weight of the GL (Denamur \& Mauléon, 1963; Kiracofe, Menzies, Gier \& Spies, 1966). Experiments in vivo (Duncan, Bowerman, Anderson, Hearn \& Melampy, 1961) and in vitro (Schomberg, 1967) showed that filtrates of the porcine endometrium collected at the end of the oestrous cycle have a luteolytic effect on the cL. Williams, Johnston, Lauterbach \& Fagan (1967), using acetone-dried powder preparations of the bovine uterus, demonstrated its luteolytic action in pseudopregnant rabbits.

The process and mode of action of uterine luteolysis are still not understood. The present experiment was undertaken to determine the effect on CL of destroying any possible vascular connections between the uterine horn and the adjacent ovary containing a CL. Ewes were injected with PMSG to induce ovulation and CL formation in both ovaries, one ovary being left intact in each ewe to serve as a control.

Fourteen Columbia ewes were placed with a vasectomized ram and checked

* Present address: Institute of Physiology and Nutrition, Polish Academy of Science, Jablonna near Warsaw, Poland. 
twice daily for oestrus during December to February. The first day of oestrus was considered as Day 1. After two control oestrous cycles of a normal length, seven ewes were injected with 750 i.u. of PMSG on Day 13 of the oestrous cycle. The other seven ewes were not treated with PMSG. Laparotomy was performed on Days 8 to 9 after the injection of PMSG. Anaesthesia was initiated with sodium pentobarbitone. The cL were marked with Indian ink and their positions on the ovaries recorded. One ovary containing a functional CL was completely separated from the uterus by severing the branches of the uterine artery and vein as well as all the smaller vessels connecting the ovary and uterus, and was similarly separated from the oviduct. All the ovarian arterial and venous

TABLE 1

EFFECT OF GUTTING THE VASCULAR AND LYMPHATIC UTERO-OVARIAN CONNEGTIONS ON THE LIFE-SPAN OF THE CORPUS LUTEUM IN SHEEP

\begin{tabular}{|c|c|c|c|c|c|}
\hline \multirow[b]{2}{*}{ Sheep no. } & \multirow[b]{2}{*}{ No. of $C L$} & \multicolumn{2}{|c|}{ Separated ovary } & \multicolumn{2}{|c|}{ Intact ovary (control) } \\
\hline & & $\begin{array}{c}\text { Ovarian } \\
\text { weight }(g)\end{array}$ & $\begin{array}{c}C L \\
\text { weight }(m g)\end{array}$ & $\begin{array}{c}\text { Ovarian } \\
\text { weight }(g)\end{array}$ & $\begin{array}{c}C L \\
\text { weight }(m g)\end{array}$ \\
\hline $\begin{array}{c}1 \\
2 \\
3 \\
4^{*} \\
5 \\
6 \\
7 \\
7 \text { to } 14 \\
\text { (control) }\end{array}$ & $\begin{array}{l}1+1 \\
1+1 \\
1+1 \\
2+0 \\
1+0 \\
1+0 \\
1+0 \\
1+0\end{array}$ & $\begin{array}{c}3 \cdot 08 \\
3.04 \\
2 \cdot 81 \\
3.55 \\
2.45 \\
4.53 \\
6.00 \\
2.53 \text { to } 3.21\end{array}$ & $\begin{array}{c}75 \\
68 \\
73 \\
67,120 \\
66 \\
112 \\
192 \\
91 \text { to } 110\end{array}$ & $\begin{array}{c}1.97 \\
2.18 \\
2.03 \\
0.99 \\
1.61 \\
2.41 \\
4.20 \\
1.83 \text { to } 2.80\end{array}$ & $\begin{array}{r}13 \\
10 \\
7 \\
- \\
- \\
- \\
-\end{array}$ \\
\hline
\end{tabular}

* Two CL in one ovary.

$\dagger$ Intact control ewes slaughtered 9 days after oestrus.

vessels were left intact. The ewes were placed with the vasectomized ram after operation to detect any post-operative cycles. Animals were slaughtered 26 days after PMSG-induced ovulation. At slaughter, the ovaries were checked for new CL. The persistent CL were removed, photographed, and fixed in $6 \%$ formalin. Six sections were cut and stained with haematoxylin and eosin for histological examination. The seven intact ewes, used as controls, were slaughtered 9 days after normal oestrus. The cL were dissected out, weighed and examined histologically. None of the ewes showed 'oestrus' behaviour before slaughter. The CL of the separated ovaries remained functional, while those with connections to the uterine horn were completely involuted (Table 1). The weight and histological characteristics of the persistent CL were comparable to those of normally cycling ewes 9 days after oestrus (Table 1 ). No follicles over $0.3 \mathrm{~mm}$ in diameter have been found. These facts suggest that the persistent cL produced a large amount of progesterone which suppressed release of hypophysial gonadotrophins.

It is concluded that the vascular connections between the ovary and the adjacent uterine horn could act as pathways for the uterine luteolytic substances. 


\section{REFERENCES}

Anderson, L. L., Bowerman, A. M. \& Melampy, R. M. (1963) Neuro-utero-ovarian relationships. In: Advances in Neuroendocrinology, p. 345. Ed. A. V. Nalbandov. University of Illinois Press, Urbana.

Bradbury, J. T., Brown, W. E. \& Gray, L. A. (1950) Maintenance of the corpus luteum and physiologic actions of progesterone. Recent Prog. Horm. Res. 5, 151.

Butcher, R. L., Chu, K. Y. \& Melampy, R. M. (1962) Utero-ovarian relationship in the guinea-pig. Endocrinology, 71, 810.

CALDWELl, B. V., MAzER, R. S. \& Wright, P. A. (1967) Luteolysis as affected by uterine transplantation in the Syrian hamster. Endocrinology, 80, 447.

Denamur, R. \& Maultén, P. (1963) Côntrole endocrinien de la persistance du corps jaune chez les ovins. C. r. hebd. Séanc. Acad. Sci., Paris, 257, 527.

Duncan, G. W., Bowerman, A. M., Anderson, L. L., Hearn, W. R. \& Melampy, R. M. (1961) Factors influencing in vitro synthesis of progesterone. Endocrinology, 68, 199.

Goding, J. R., McGracken, J. A. \& Baird, D. T. (1967) Study of ovarian function in the ewe by means of vascular autotransplantation technique. 7. Endocr. 39, 37.

Kiracofe, G. H., Menzres, G. S., Grer, H. T. \& Sires, H. G. (1966) Effect of uterine extracts and uterine or ovarian blood vessel ligations on ovarian function of ewes. J. Anim. Sci. 25, 1159.

MCCRAGKEN, J. A. \& BAIRD, D. T. (1969) The study of ovarian function by means of transplantation of the ovary in the ewe. In: The Gonads. Ed. K. McKerns. Appleton Century Grofts, New York.

Melampy, R. M., Anderson, L. L. \& KraGt, C. L. (1964) Uterus and life span of rat corpora lutea. Endocrinology, 74, 501.

SchomberG, D. W. (1967) Demonstration in vitro of luteolytic activity in pig uterine flushings. $\mathcal{f}$. Endocr. 38, 359.

Williams, W. F., Johnston, J. O., Lauterbach, M. \& Fagan, B. (1967) Luteolytic effect of a bovine uterine powder on the corpora lutea, follicular development, and progesterone synthesis of the pseudopregnant rabbit ovary. F. Dairy Sci. 50, 555. 